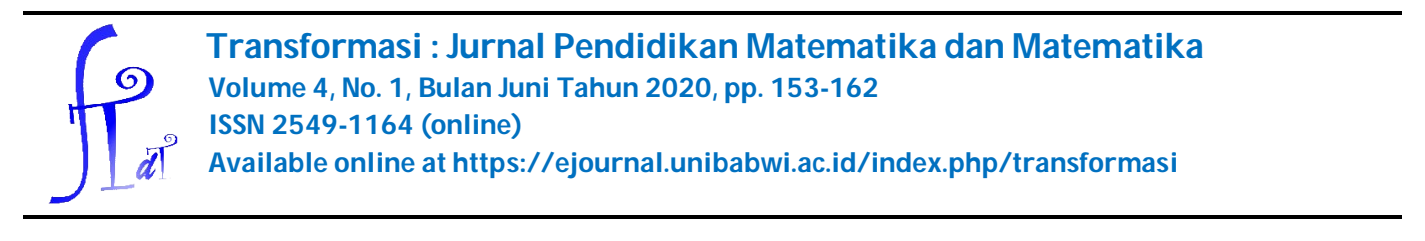

\title{
ANALISIS KEMAMPUAN PEMECAHAN MASALAH SISWA PADA MATERI SISTEM PERSAMAAN LINEAR TIGA VARIABEL
}

\author{
Rini Husna Azzahra ${ }^{1}$, Heni Pujiastuti ${ }^{2}$ \\ 1,2 FKIP, Universitas Sultan Ageng Tirtayasa \\ email korespondensi : rinihusna28@gmail.com
}

Diterima :29-04-2020, Revisi: 01-06-2020, Diterbitkan : 25-06-2020

\begin{abstract}
ABSTRAK
Penelitian ini bertujuan untuk mengetahui kemampuan pemecahan masalah siswa pada materi sistem persamaan linear tiga variabel berdasarkan tahapan Polya. Jenis penelitian ini adalah penelitian deskriptif kualitatif. Subjek penelitian ada 30 siswa kelas X IPS 3 SMAN 5 Kota Serang dan diambil 6 siswa dari kategori tinggi, sedang, dan rendah. Teknik pengumpulan data yang digunakan adalah tes. Instrumen tes yang diberikan sebanyak 3 butir soal berbentuk soal cerita. Subjek dianalisis berdasarkan indikator tahapan Polya, yaitu memahami masalah, merencanakan penyelesaian, melaksanakan rencana, dan memeriksa kembali proses dan hasil. Hasil dari penelitian ini menunjukkan bahwa kemampuan pemecahan masalah siswa kelas X IPS 3 SMAN 5 Kota Serang masih rendah. Hal ini karena : (1) pada tahap memahami masalah siswa belum sepenuhnya memahami masalah materi sistem persamaan linear tiga variabel; (2) pada tahap merencanakan penyelesaian siswa kesulitan dalam menuliskan strategi/ rencana untuk menyelesaikan masalah; (3) pada tahap melaksanakan rencana penyelesaian siswa tidak melakukan proses perhitungan dengan benar dan tidak menemukan solusi yang tepat; dan (4) pada tahap memeriksa kembali siswa hanya sampai pada perolehan solusi tanpa memeriksa kembali dengan mensubstitusi ke persamaan awal dan juga tidak membuat kesimpulan.
\end{abstract}

Kata kunci : Kemampuan Pemecahan Masalah, Sistem Persamaan Linear Tiga Variabel. 


\begin{abstract}
This study aims to determine students' problem solving abilities in the material system of linear three-variable equations based on Polya's stages. This type of research is a qualitative descriptive study. The research subjects were 30 students of class X IPS 3 of SMAN 5 in Serang City and 6 students were taken from the high, medium, and low categories. The data collection technique used is a test. Test instruments were given as many as 3 items in the form of story questions. Subjects were analyzed based on Polya's stage indicators, namely understanding the problem, planning a solution, implementing the plan, and re-examining the process and results. The results of this study show that the problem solving ability of class X IPS 3 students of SMAN 5 Serang City is still low. This is because : (1) at the stage of understanding the problem students have not yet fully understood the material problem of the three-variable linear equation system; (2) at the stage of planning the solution students have difficulty writing strategies / plans to solve the problem; (3) at the stage of implementing the completion plan students do not do the calculation process correctly and do not find the right solution; and (4) at the stage of re-checking students only arrive at the solution without checking back by substituting the initial equation and also not making conclusions.
\end{abstract}

Keywords : Problem Solving Capability, Three Variable Linear Equation System.

\title{
Pendahuluan
}

Salah satu tujuan utama dalam pembelajaran matematika adalah siswa memiliki kemampuan pemecahan masalah (Hadi \& Radiyatul, 2014). Gagne (Zakiyah et al., 2019) mengemukakan bahwa pemecahan masalah merupakan tahapan belajar paling tinggi diantara pembelajaran yang lainnya. Menurut Utami (Amalia \& Widodo, 2018) secara sadar maupun tidak, kita sering dihadapkan dengan berbagai permasalahan dalam kehidupan sehari-hari yang menuntut kemampuan pemecahan masalah. Oleh karena itu, kemampuan pemecahan masalah penting dimiliki siswa agar terbiasa memecahkan masalah dalam kehidupan sehari-hari.

Menurut Branca (Purnamasari \& Setiawan, 2019) pemecahan masalah termasuk salah satu kemampuan yang harus dikuasai oleh siswa, karenanya pemecahan masalah disebut sebagai jantungnya matematika. Robert L. Solso (Sumargiyani \& Hibatallah, 2018) mengemukakan bahwa pemecahan masalah merupakan pemikiran terarah untuk menemukan solusi dari suatu masalah yang spesifik. Sejalan dengan hal tersebut, Hidayat dan Sariningsih (Zakiyah et al., 2019) berpendapat bahwa dalam menyelesaikan suatu permasalahan diperlukan beberapa keterampilan dalam memahami sebuah masalah, membuat suatu model matematika dari permasalahan tersebut, menyelesaikan masalah dan menafsirkan solusinya.

Langkah-langkah menurut Polya adalah salah satu langkah-langkah dalam 
memecahkan masalah. Terdapat empat langkah Polya (Indrawati et al., 2019) yaitu (1) memahami masalah (understanding the problem), (2) menyusun rencana penyelesaian (devise a plan), (3) melaksanakan rencana penyelesaian (carry out the plan), dan (4) memeriksa kembali (looking back). Menurut Jonassen (Indahsari \& Fitrianna, 2019) dalam kegiatan pemecahan masalah dapat dilakukan dengan mengerjakan soal cerita. Dari soal cerita tersebut siswa dituntut untuk menyelesaikan soal dengan mengubah soal dalam bentuk matematika dan menyelesaikan soal berdasarkan apa yang diketahui pada soal berdasarkan prosedur matematika (Juliana et al., 2017).

Kemampuan pemecahan masalah setiap siswa berbeda, hal ini bisa dilihat dari beberapa hasil penelitian sebelumnya yang telah meneliti kemampuan pemecahan masalah matematika siswa. Siahaan, et al. (2018) dalam penelitiannya menyimpulkan bahwa terdapat perbedaan kemampuan pemecahan masalah matematis antara keenam subjek pada langkah menyelesaikan masalah dan mengecek kembali, yaitu subjek FI dalam menyelesaikan masalah sesuai rencana dan mengecek kembali hasil yang diperoleh lebih baik dibandingkan subjek FD dalam menyelesaikan masalah dan mengecek kembali hasil. Penelitian Sudirman \& Zanthy (2019) menunjukkan bahwa dari sebanyak 40 siswa kelas X hanya 4 orang siswa saja yang dapat menyelesaikan penyimpulan, 13 siswa menyelesaikan keterampilan proses, 24 siswa menyelesaikan tahap transformasi, dan 32 siswa dapat meyelesaikan tahap pemahaman masalah. Artinya kemampuan pemecahan masalah pada kelas X di salah satu Madrasah Aliyah di Cianjur masih lemah. Penelitian Zulfitri (2019) menunjukkan bahwa indikator kemampuan pemecahan masalah yang sering muncul adalah indikator memahami masalah yang muncul disetiap tingkat kemampuan siswa yaitu tinggi, sedang, dan rendah. Indikator melihat kembali hanya muncul pada tingkat kemampuan siswa yang tinggi saja, tetapi untuk tingkat kemampuan siswa yang sedang dan rendah indikator ini tidak muncul.

Salah satu materi yang ada pada pelajaran matematika adalah materi Sistem Persamaan Linier Tiga Variabel (SPLTV). Materi tersebut sering berbentuk soal cerita karena erat kaitannya dalam kehidupan sehari-hari, seperti menghitung harga sebuah barang yang hanya diketahui total belanja dari beberapa barang tanpa tahu harga satuan barang yang dibeli. Adapun Kompetensi Dasar (KD) pada materi ini adalah menyusun sistem persamaan linier tiga variabel dari masalah kontekstual yang berkaitan dengan sistem persamaan linier tiga variabel. Berdasarkan kompetensi dasar tersebut, siswa harus memiliki kemampuan pemecahan masalah yang baik agar mampu menyelesaikan persoalan tersebut.

Berdasarkan pemaparan di atas, penting bagi siswa untuk memiliki kemampuan pemecahan masalah. Untuk itu dilakukan penelitian dengan judul "Analisis Kemampuan Pemecahan Masalah Siswa pada Materi Sistem Persamaan Linear Tiga Variabel". Tujuan dari penelitian ini untuk mengetahui kemampuan pemecahan 
masalah siswa pada materi sistem persamaan linear tiga variabel berdasarkan tahapan Polya.

\section{Metode Penelitian}

Jenis penelitian yang digunakan adalah penelitian deskriptif kualitatif. Penelitian deskriptif kualitatif bertujuan untuk menggambarkan secara utuh dan mendalam mengenai realita sosial yang terjadi. Adapun penelitian ini bertujuan untuk mengetahui kemampuan pemecahan masalah siswa pada materi sistem persamaan linear tiga variabel.

Penelitian ini diawali dengan pemberian Tes Pemecahan Masalah kepada 30 orang siswa kelas X IPS 3 di SMAN 5 Kota Serang. Kemudian 6 orang diambil sebagai subjek penelitian dari kategori kemampuan tinggi, sedang, dan rendah. Pemilihan subjek penelitian diambil dengan purposive sampling dengan klasifikasi kategori berdasarkan Subekti, Untarti, dan Muhammad (Anggraeni \& Widayanti, 2019).

Tabel 1. Klasifikasi Kategori

\begin{tabular}{cc}
\hline Rentang Nilai & Kategori \\
\hline $\mathrm{x} \geq$ (nilai rata-rata + standar deviasi) & Tinggi \\
(nilai rata-rata - standar deviasi) $<\mathrm{x}<$ (nilai rata-rata + & Sedang \\
standar deviasi) & Rendah \\
\hline $\mathrm{x} \leq$ (nilai rata-rata - standar deviasi) &
\end{tabular}

Instrumen yang digunakan adalah instrumen tes. Instrumen tes terdiri dari 3 butir soal berbentuk soal cerita open ended. Tes dibuat berdasarkan indikator kemampuan pemecahan masalah menurut Polya (Amalia \& Widodo, 2018), yaitu : (1) memahami masalah (understanding the problem), (2) merencanakan penyelesaian (devising a plan), (3) melaksanakan rencana (carrying out the plan), dan (4) memeriksa kembali proses dan hasil (looking back).

Teknik analisis data yang digunakan adalah analisis data deskriptif kualitatif, yang meliputi : reduksi data, penyajian data, dan penarikan kesimpulan. Analisis deskriptif dilakukan berdasarkan hasil nilai tes pemecahan masalah siswa berdasarkan tahapan Polya. Berikut ini kriteria pemberian skor untuk indikator kemampuan pemecahan berdasarkan tahapan Polya (Akbar, et al., 2017). 
Tabel 2. Kriteria Penskoran Kemampuan Pemecahan Masalah Berdasarkan Tahapan Polya

\begin{tabular}{|c|c|c|}
\hline Aspek Penilaian & Keterangan & Skor \\
\hline \multirow{4}{*}{$\begin{array}{l}\text { Memahami masalah } \\
\text { (understanding the } \\
\text { problem) }\end{array}$} & $\begin{array}{l}\text { Tidak menyebutkan apa yang diketahui dan } \\
\text { apa yang ditanyakan }\end{array}$ & 0 \\
\hline & $\begin{array}{l}\text { Menyebutkan apa yang diketahui tanpa } \\
\text { menyebutkan apa yang ditanyakan, atau } \\
\text { sebaliknya }\end{array}$ & 1 \\
\hline & $\begin{array}{l}\text { Menyebutkan apa yang diketahui dan } \\
\text { menyebutkan apa yang ditanyakan namun } \\
\text { belum tepat. }\end{array}$ & 2 \\
\hline & $\begin{array}{l}\text { Menyebutkan apa yang diketahui dan } \\
\text { menyebutkan apa yang ditanyakan dengan } \\
\text { tepat }\end{array}$ & 3 \\
\hline \multirow{3}{*}{$\begin{array}{c}\text { Merencanakan } \\
\text { penyelesaian (devising } \\
\text { a plan) }\end{array}$} & $\begin{array}{l}\text { Tidak merencanakan penyelesaian masalah } \\
\text { sama sekali }\end{array}$ & 0 \\
\hline & $\begin{array}{l}\text { Merencanakan penyelesaian masalah namun } \\
\text { belum tepat }\end{array}$ & 1 \\
\hline & $\begin{array}{l}\text { Merencanakan penyelesaian masalah dengan } \\
\text { tepat. }\end{array}$ & 2 \\
\hline \multirow{4}{*}{$\begin{array}{l}\text { Melaksanakan rencana } \\
\text { (carrying out the plan) }\end{array}$} & $\begin{array}{l}\text { Tidak menyelesaikan permasalahan sama } \\
\text { sekali. } 1\end{array}$ & 0 \\
\hline & $\begin{array}{l}\text { Melaksanakan rencana namun salah atau } \\
\text { benar sebagian kecil saja. }\end{array}$ & 1 \\
\hline & $\begin{array}{l}\text { Melaksanakan rencana namun sedikit ada } \\
\text { kesalahan atau benar setengah }\end{array}$ & 2 \\
\hline & Melaksanakan rencana dengan benar dan tepat & 3 \\
\hline \multirow{3}{*}{$\begin{array}{l}\text { Memeriksa kembali } \\
\text { proses dan hasil } \\
\text { (looking back) }\end{array}$} & Tidak melakukan proses pengecekkan kembali. & 0 \\
\hline & $\begin{array}{l}\text { Melakukan pengecekkan kembali namun } \\
\text { belum tepat. }\end{array}$ & 1 \\
\hline & $\begin{array}{l}\text { Melakuka pegecekkan kembali dengan benar } \\
\text { dan tepat }\end{array}$ & 2 \\
\hline
\end{tabular}

\section{Hasil dan Pembahasan}

Dalam pengambilan data, peneliti memberikan soal Tes Kemampuan Pemecahan Masalah kepada 30 orang siswa kelas X IPS 3 di SMAN 5 Kota Serang. Data yang diperoleh kemudian dianalisis dan dideskripsikan sesuai dengan indikator yang telah ditentukan. Hasil dari tes kemampuan pemecahan masalah siswa pada materi sistem persamaan linear tiga variabel dapat dilihat pada tabel berikut. 
Tabel 3. Data Hasil Soal Tes Kemampuan Pemecahan Masalah

\begin{tabular}{clc}
\hline No & \multicolumn{1}{c}{ Data } & Nilai \\
\hline 1. & Nilai rata-rata & 46,56 \\
2. & Standar deviasi & 22,46 \\
3. & Nilai Minimum & 20 \\
4. & Nilai Maksimum & 100 \\
5. & Nilai rata-rata - standar deviasi & 69,02 \\
6. & Nilai rata-rata - standar deviasi & 24,10 \\
\hline
\end{tabular}

Berdasarkan tabel 3 di atas, data dapat diklasifikasikan ke dalam kategori yang ada pada tabel 4. Berikut hasil soal tes dipaparkan dalam klasifikasi kategori.

Tabel 4. Klasifikasi Kategori Dari Hasil Soal Tes

\begin{tabular}{cccc}
\hline Rentang Nilai & Kategori & Jumlah siswa & Presentase \\
\hline Nilai $\geq 69,02$ & Tinggi & 5 & $16,67 \%$ \\
\hline $24,10<$ Nilai $<69,02$ & Sedang & 21 & $70 \%$ \\
\hline $24,10 \leq$ Nilai & Rendah & 4 & $13,33 \%$ \\
\hline
\end{tabular}

Berdasarkan klasifikasi kategori tersebut, peneliti memilih 6 orang sebagai subjek penelitian. Peneliti memilih masing-masing 2 orang dari kategori tinggi, sedang, dan rendah. Peneliti memilih dari 3 kategori berbeda karena peneliti ingin mengetahui kemampuan pemecahan masalah siswa dari tingkat kemampuan yang berbeda. Berikut hasil pemilihan subjek penelitian.

Tabel 5. Hasil Pemilihan Subjek Penelitian

\begin{tabular}{cccc}
\hline No & Kode Siswa & Nilai & Kategori \\
\hline 1. & S1 & 100 & Tinggi \\
2. & S2 & 76,67 & Tinggi \\
3. & S3 & 40 & Sedang \\
4. & S4 & 36,67 & Sedang \\
5. & S5 & 23,33 & Rendah \\
6. & S6 & 20 & Rendah \\
\hline
\end{tabular}

Subjek yang telah dipilih dianalisis oleh peneliti sesuai dengan indikator kemampuan pemecahan masalah. Berikut pembahasan mengenai kemampuan pemecahan masalah siswa.

\section{Tahapan Memahami Masalah}

Berdasarkan 6 subjek yang dipilih, hanya siswa kategori tinggi yang mampu menuliskan apa yang diketahui dan ditanyakan dari ketiga soal secara lengkap dan sesuai dengan informasi, yaitu S1 dan S2. Siswa kategori sedang, yaitu S3 dan S4, dapat menuliskan apa yang diketahui dan ditanyakan, tetapi hanya soal nomor 1 saja yang dituliskan secara lengkap dan sesuai. Sedangkan pada soal nomor 2 dan 3 tidak 
ditulis secara lengkap dan belum sesuai dengan informasi yang diberikan. S5 hanya dapat menuliskan apa yang diketahui dan ditanyakan pada soal nomor 1 , sedangkan soal nomor 2 dan 3 tidak dijawab. S6 hanya menuliskan apa yang diketahui saja pada soal nomor 1, sedangkan pada soal nomor 2 ditulis apa yang diketahui saja tetapi belum sesuai informasi, dan pada soal nomor 3 tidak dijawab. Hal ini menunjukkan bahwa siswa belum sepenuhnya memahami masalah materi sistem persamaan linear tiga variabel. Hal ini sejalan dengan (Yuwono, et al., 2018) bahwa penyebab kesalahan siswa pada tahap ini adalah kurangnya pemahaman terhadap materi.

\section{Tahapan Merencanakan Penyelesaian}

Pada tahap ini, hanya S1 yang dapat merencanakan penyelesaian dengan baik pada ketiga soal. S2 dapat merencanakan penyelesaian pada soal nomor 1 dan 2 dengan baik, tetapi tidak merencanakan penyelesaian pada nomor 3. S3 dan S4 melakukan kesalahan merencanakan penyelesaian pada nomor 2 dan 3 . Sedangkan S5 dan S6 tidak menjawab soal nomor 2 dan 3. Hal ini menunjukkan bahwa siswa kesulitan dalam menuliskan strategi/ rencana untuk menyelesaikan masalah. Sari \& Wijaya (Utami \& Wutsqa, 2017) berpendapat siswa salah mentransformasikan masalah pada model matematika dikarenakan kesulitan dalam menganalisis fakta yang ada pada soal untuk dikaitkan dengan konsep matematis yang relevan.

\section{Tahapan Melaksanakan Rencana Penyelesaian}

Dalam tahap melaksanakan rencana penyelesaian, siswa banyak melakukan kesalahan. Hanya S1 yang dapat melaksanakan rencana penyelesaian secara baik pada ketiga nomor. S2 hanya dapat melaksanakan rencana penyelesaian dengan baik pada nomor 1 dan 2. Sedangkan S3, S4, S5, dan S6 melakukan kesalahan ketika melaksanakan rencana penyelesaian. Kesalahan itu dikarenakan siswa tidak melakukan proses perhitungan dengan benar dan tidak menemukan solusi yang tepat. Penguasaan perhitungan dan ketelitian sangat diperlukan dalam tahap ini, karena kesalahan yang terjadi disebabkan oleh kurang telitinya dalam menyelesaikan masalah dan kekeliruan proses perhitungan yang dilakukan (Wilujeng, 2018). Sebab lainnya yaitu proses penyelesaian yang tidak selesai dikarenakan waktu sudah habis sebelum siswa menyelesaikan masalah. Hal ini sejalan dengan Zulfitri (2019) bahwa penyebab siswa keliru dalam penyelesaian masalah adalah siswa salah dalam membuat rencana pada indikator pemecahan masalah yang kedua sehingga proses penyelesaian masalah juga salah dan kekeliruan dalam proses perhitungan.

\section{Tahapan Memeriksa Kembali}

Pada tahap memeriksa kembali siswa mengecek semua perhitungan dan solusi yang telah diperoleh dengan mensubstitusi. Sama halnya dengan penelitian Zulfitri (2019) indikator memeriksa kembali merupakan indikator yang paling jarang muncul. 
Indikator ini hanya muncul pada S1 dan S2 yang merupakan subjek kelompok tinggi. Sementara S3, S4, S5 dan S6 tidak melakukan tahap memeriksa kembali. Hal ini menunjukkan bahwa siswa hanya sampai pada perolehan solusi tanpa memeriksa kembali dengan mensubstitusi ke persamaan awal dan juga tidak membuat kesimpulan. Oleh karena itu, banyak siswa yang menemukan solusi namun bukan solusi yang tepat. Selain itu siswa juga tidak menyelesaikan pengerjaan sehingga tidak melaksanakan tahap memeriksa kembali.

\section{Kesimpulan}

Berdasarkan hasil dan pembahasan penelitian yang telah dijabarkan, maka dapat disimpulkan bahwa kemampuan pemecahan masalah siswa kelas X IPS 3 SMAN 5 Kota Serang masih rendah. Hal ini dikarenakan sebagai berikut.

1. Pada tahap memahami masalah, siswa belum sepenuhnya memahami masalah materi sistem persamaan linear tiga variabel. Hal ini dilihat dari enam siswa, hanya siswa kelompok tinggi yang mampu menuliskan apa yang diketahui dan ditanyakan secara lengkap dan sesuai dengan soal yang diberikan.

2. Pada tahap merencanakan penyelesaian, siswa kesulitan dalam menuliskan strategi/ rencana untuk menyelesaikan masalah. Hanya siswa kelompok tinggi yang dapat merencanakan penyelesaian dengan baik, sementara siswa kelompok sedang dan rendah masih melakukan kesalahan.

3. Pada tahap melaksanakan rencana penyelesaian, siswa tidak melakukan proses perhitungan dengan benar dan tidak menemukan solusi yang tepat. Hal ini disebabkan siswa tidak melaksanakan tahap merencanakan penyelesaian dengan baik.

4. Pada tahap memeriksa kembali, siswa hanya sampai pada perolehan solusi tanpa memeriksa kembali dengan mensubstitusi ke persamaan awal dan juga tidak membuat kesimpulan. Hal ini disebabkan siswa tidak menyelesaikan rencana penyelesaian dengan baik.

\section{Ucapan Terimakasih}

Ucapan terimakasih ditujukan pada siswa kelas X IPS 3 SMAN 5 Kota Serang sebagai subjek penelitian dan pihak-pihak yang telah mendukung keterlaksanaan penelitian ini.

\section{Daftar Pustaka}

Akbar, P., Hamid, A., Bernard, M., \& Sugandi, A. I. (2017). Analisis Kemampuan Pemecahan Masalah Dan Disposisi Matematik Siswa Kelas XI SMA Putra Juang Dalam Materi Peluang. Jurnal Cendekia: Jurnal Pendidikan Matematika, 2(1), 
144-153. https:// doi.org/ 10.31004/ cendekia.v2i1.62

Amalia, S. R., \& Widodo, A. N. A. (2018). Analisis Kemampuan Pemecahan Masalah

Mahasiswa Melalui Model PBL Berbasis Etnomatematika Ditinjau Dari

Kepribadian Topologi Hippocrates Dan Galenus Tipe Cholearis Dan

Phlegmantis. AKSIOMA : Jurnal Matematika Dan Pendidikan Matematika, 9(1), 1. https:// doi.org/ 10.26877/ aks.v9i1.2467

Anggraeni, S. A., \& Widayanti, E. (2019). Analisis Kemampuan Komunikasi Matematis

Siswa Dalam Menyelesaikan Soal Open Ended pada Materi Aritmetika Sosial

Kelas VII SMP. Transformasi : Jurnal Pendidikan Matematika dan Matematika 3(2), 115-128.

Hadi, S., \& Radiyatul, R. (2014). Metode Pemecahan Masalah Menurut Polya untuk Mengembangkan Kemampuan Siswa dalam Pemecahan Masalah Matematis di Sekolah Menengah Pertama. EDU-MAT: Jurnal Pendidikan Matematika, 2(1), 53-61. https:/ / doi.org/ 10.20527/ edumat.v2i1.603

Indahsari, A. T., \& Fitrianna, A. Y. (2019). Analisis Kemampuan Pemecahan Masalah

Siswa Kelas X Dalam Menyelesaikan SPLDV. JPMI (Jurnal Pembelajaran Matematika Inovatif), 2(2), 77. https:/ / doi.org/ 10.22460/ jpmi.v2i2.p77-86

Indrawati, K. A. D., Muzaki, A., \& Febrilia, B. R. A. (2019). Profil Berpikir Siswa dalam

Menyelesaikan Soal Sistem Persamaan Linear.Jurnal Didaktik Matematika, 6(1), 69-84. https:/ / doi.org/ 10.24815/jdm.v6i1.12200

Juliana, Ekawati, D., \& Basir, F. (2017). Deskripsi Kemampuan Pemecahan Masalah

Matematika Siswa Dalam Menyelesaikan Soal Sistem Persamaan Linear Dua Variabel. Jurnal Ilmiah Program Studi Pendidikan Matematika STKIP Siliwangi Bandung, 2(1), 121-133.

Purnamasari, I., \& Setiawan, W. (2019). Analisis Kemampuan Pemecahan Masalah

Matematis Siswa SMP pada Materi SPLDV Ditinjau dari Kemampuan Awal Matematika. Journal of Medives: Journal of Mathematics Education IKIP Veteran Semarang, 3(2), 207. https:/ / doi.org/ 10.31331/ medivesveteran.v3i2.771

Siahaan, E. ., Dewi, S., \& Said, H. . (2018). Analisis Kemampuan Pemecahan Masalah Matematis Berdasarkan Teori Polya Ditinjau Dari Gaya Kognitif Field Dependent Dan Field Independent Pada Pokok Bahasan Trigonometri Kelas X SMAN 1 Kota Jambi. Phi:Jurnal Pendidikan Matematika, 2(2), 100-110. https:/ / doi.org/ 10.1017/ CBO9781107415324.004

Sumargiyani, \& Hibatallah, M. I. (2018). Analisis Kemampuan Pemecahan Masalah 
Siswa pada Materi Barisan dan Deret Siswa XI IPA MA Ali Maksum. Prosiding

Seminar Nasional Pendidikan Matematika Etnomatnesia, 0(0), 891-900. http:/ / jurnal.ustjogja.ac.id/ index.php/ etnomatnesia/ article/ view/ 2433

Utami, R. W., \& Wutsqa, D. U. (2017). Analisis Kemampuan Pemecahan Masalah Matematika dan Self-efficacy Siswa SMP Negeri di Kabupaten Ciamis. Jurnal

$\begin{array}{llll}\text { Riset Pendidikan } & \text { Matematika, }\end{array}$

https:// doi.org/ 10.21831/jrpm.v4i2.14897

Wilujeng, H. (2018). ANALISIS KEMAMPUAN PEMECAHAN MASALAH MATEMATIKA Science Study ( TIMSS ). 2(2).

Yuwono, T., Supanggih, M., \& Ferdiani, R. D. (2018). Analisis Kemampuan Pemecahan

Masalah Matematika dalam Menyelesaikan Soal Cerita Berdasarkan Prosedur

Polya. Jurnal Tadris Matematika, 1(2), 137-144.

https:// doi.org/ 10.21274/ jtm.2018.1.2.137-144

Zakiyah, S., Hidayat, W., \& Setiawan, W. (2019). Analisis Kemampuan Pemecahan Masalah dan Respon Peralihan Matematik dari SMP ke SMA pada Materi SPLTV. Mosharafa: Jurnal Pendidikan Matematika, 8(2), 227-238. https:/ / doi.org/ 10.31980/ mosharafa.v8i2.437

Sudirman, S. \& Zanthy, L. S. (2019). Analisis Kemampuan Pemecahan Masalah Matematis Siswa MA Menggunakan Pendekatan Problem Based Learning. Journal on Education 01(02), 198-206.

Zulfitri, H. (2019). Analisis Kemampuan Pemecahan Masalah Matematika Setelah Pembelajaran dengan Pendekatan MEAs pada Materi Sistem Persamaan Linier Tiga Variabel. Jurnal Gantang, 4, 7-13. https:/ / doi.org/ 10.31629/ jg.v4i1.881 